Олег Березюк

ВПРОВАДЖЕННЯ ПРАКТИЧНОГО ЗАНЯТТЯ «ДОСЛУДЖЕННЯ ЗАБРУДНЕННЯ НАВКОЛИШНЬОГО СЕРЕДОВИЩА ТВЕРДИМИ ПОБУТОВИМИ ВІДХОДАМИ ТА РОЗР АХУНОК ПАР АМЕТРІВ МАШИН ТА ОБЛАДНАННЯ ДЛЯ МІНІМІАЦЇ̈ НЕГАТИВ НОГО ВПЛИВУ НА НЬОГО» 3 ДИСЦИПЛІНИ БЕЗПЕКА ЖИТТЕДІЯЛЬНОСТІ

Під час підготовки майбутніх фахівців у Вінницькому національному технічному універс итеті викладається нормативна дисципліна «Безпека життєдіяльності» (БЖД) («Типова навчальна програма нормативної дисципліни «Безпека життсдіяльності» для вищих навчальних закладів», 2011; Кобилянський, 2012), в процесі вивчення якої розглядаються, зокрема, питання охорони навколишнього природного середовища. При цьому вивчаються основні джерела забруднення атмосфери, гідросфери та літосфери, негативний вплив забруднень та методи зменшення інтенсивності та запобігання забрудненням. В той же час питанням забруднення навколишнього середовища твердими побутов ими відходами (ТПВ) та розрахунку параметрів машин та обладнання для мінімізації негативного впливу на нього приділяється недостатньо уваги.

Метою роботи є розробка методики інженерних розрахунків, необхідної для впровадження практичного заняття «Дослідження забруднення навколишнього середовища твердими побутовими відходами та розрахунок параметрів машин та обладнання для мінімізації негативного впливу на нього» 3 дис ципліни безпека життєдіяльності для сприяння поглибленню знань 3 питань охорони навколишнього природного середовища майбутніх фахівців.

\title{
Результати дослідження
}

Найбільш поширеними серед відомих шляхів поводження з ТПВ є захоронення на полігонах та сміттєзвалищах, спалювання 3 використанням енергії, компостування, повторне використання ТПВ. Поширеність цих методів поводження 3 ТПВ може буги описана залежностями (О. Березюк, 2011, 2016а; О. Березюк, \& Л. Березюк, 2016):

$$
\begin{aligned}
& \Pi_{\text {зах }}^{\text {ТПВ }}=22,19-16,33 \frac{n_{H}}{S_{к р}}-6,546 \frac{B B \Pi}{n_{н}}+49,94 \frac{B_{\text {спал }}}{B_{\text {зах }}}+0,4575 \frac{n_{н}}{S_{к р}} \frac{B B \Pi}{n_{н}}+6,267 \frac{n_{н}}{S_{\text {кр }}} \frac{B_{\text {спал }}}{B_{\text {зах }}}+2,319 \times \\
& \times \frac{B В П}{n_{\text {н }}} \frac{B_{\text {спал }}}{B_{\text {зах }}}-0,178 \frac{n_{н}}{S_{\kappa р}} \frac{B В \Pi}{n_{н}} \frac{B_{\text {спал }}}{B_{\text {зах }}}-1,549 \cdot 10^{-3}\left(\frac{n_{H}}{S_{\kappa р}}\right)^{2}+0,0282\left(\frac{B B \Pi}{n_{н}}\right)^{2}-7,993\left(\frac{B_{\text {спал }}}{B_{\text {зах }}}\right)^{2}[\%]
\end{aligned}
$$

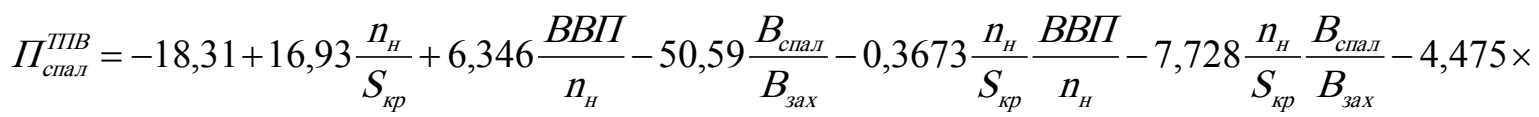

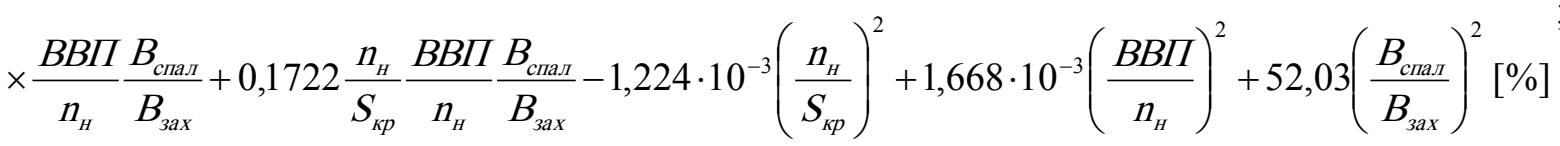

$$
\begin{aligned}
& \Pi_{\text {коми }}^{T \Pi B}=10 \\
& +2,667 \frac{B B \Pi}{n_{u}} I P Л \Pi-2,498 \cdot 10^{-3} \frac{B B \Pi}{n_{u}} U+3,236 \cdot 10^{-3} \frac{B B \Pi}{n_{u}} \Pi_{c h}+0,3217 I P Л \Pi \cdot \cdot U+0,897 I P Л I \cdot \cdot \Pi_{c u}-2,319 \cdot 10^{-5}\left(\frac{n_{u}}{S_{x p}}\right)^{2}-1,488 \cdot 10^{-3} \Pi_{c h}^{2}
\end{aligned}
$$




$$
\begin{aligned}
& \Pi_{\Pi B}^{T \Pi B}=10^{-0,393} \frac{n_{u}}{S_{k p}}-5,465 \frac{B B \Pi}{n_{n}}-2,179 I P Л \Pi+4,725 \amalg+0,3162 \frac{n_{u}}{S_{\kappa p}} I P Л \Pi+0,03271 \frac{n_{u}}{S_{k p}} \Pi P+4,853 \frac{B B \Pi \Pi}{n_{u}} I P Л \Pi-0,0221 \frac{B B \Pi \Pi}{n_{u}} \amalg- \\
& -0,1973 \frac{B B \Pi}{n_{H}} \Pi P-3,558 I P Л \Pi \cdot \amalg+3,571 \cdot 10^{-5}\left(\frac{n_{H}}{S_{k p}}\right)^{2}+0,02859\left(\frac{B B \Pi}{n_{H}}\right)^{2}-7,419 I P Л \Pi \Pi^{2}-4,607 \cdot 10^{-3} W^{2}+0,9605 \Pi P^{2}
\end{aligned}
$$

де $n_{h} / S_{k p}-$ густота населення, осіб/км²

$B B \Pi / n_{н}-$ ВВП на душу населення, тис. \$/осіб;

$B_{\text {спал }} / B_{3 a x}-$ співвідношення витрат на спалювання $B_{\text {спал }}$ та витрат на захоронення $B_{3 a x}$ ТПВ;

$n_{н}-$ кількість населення країни, осіб;

$S_{\kappa p}-$ площа території країни, км²;

IРЛП - індекс розвитку людського потенціалу $($ ІРЛП = $0 \ldots 1)$;

$U$ - середня географічна широта, ${ }^{\circ}$ пн. ш.;

$\Pi_{c H}$ - частка сільського населення, \%;

ПР - значення показника статусу держави за фактором «природні ресурси».

При захороненні ТПВ на полігонах та сміттєзвалищах відбувається забруднення грунтів важким и металами, які разом із фільтратом можуть потрапляти до підземних вод, забруднюючи ïx, що становить загрозу для безпеки життя і діяльності людини.

Кратності перевищення граничнодопустимої конщентрації (ГДК) важких металів у грунтах на різних відстанях $l$ від полігонів захоронення ТПВ можуть бути визначені за формулами (О. Березюк, 2016b):

$$
\begin{gathered}
C / Г Д К_{M n}=\frac{1}{0,3198+3,651 \cdot 10^{-4} 1} ; \\
C / Г Д К_{P b}=6,584 \cdot 0,9976^{I} .
\end{gathered}
$$

За відомими значеннями концентрації $C$ важких металів у грунтах та їхніх $\Gamma Д К$, наведених в табл. 1, можна визначити розміри зон забруднення $l$ грунт ів, прилеглих до полігонів захоронення ТПВ важкими металами.

Таблиця 1 - ГДК важких металів у грунті

\begin{tabular}{|c|c|c|c|c|c|c|c|c|c|}
\hline $\begin{array}{c}\text { Важкі } \\
\text { метали }\end{array}$ & $\begin{array}{c}\text { кадмій } \\
\mathrm{Cd}\end{array}$ & $\begin{array}{c}\text { цинк } \\
\mathrm{Zn}\end{array}$ & $\begin{array}{c}\text { свинець } \\
\mathrm{Pb}\end{array}$ & $\begin{array}{c}\text { кобальт } \\
\mathrm{Co}\end{array}$ & $\begin{array}{c}\text { мідь } \\
\mathrm{Cu}\end{array}$ & $\begin{array}{c}\text { нікель } \\
\mathrm{Ni}\end{array}$ & $\begin{array}{c}\text { хром } \\
\mathrm{Cr}\end{array}$ & $\begin{array}{c}\text { ванадій } \\
\mathrm{V}\end{array}$ & $\begin{array}{c}\text { марга- } \\
\text { нець Mn }\end{array}$ \\
\hline ГДК, мг/кг & 20 & 23 & 32 & 50 & 55 & 85 & 100 & 150 & 1500 \\
\hline
\end{tabular}

Одним із методів очищення грунтів від забруднення важкими металами є метод електрохімічної ремедіації (Лысенко, Пономарев, \& Корнилович, 2001), оснований на використанні електричного струму для виділення відповідних забруднюючих речовин.

Пигомі енерговиграти очищення грунтів полігонів ТПВ методом електрохім ічної ремедіації від забруднення важкими металами визначаються за формулою (Березюк, 2015a, 2015c, 2017)

$$
E=205,4+61,61 \sqrt[4]{\Gamma Д К-20}-\left(98,59-\frac{1230}{\Gamma Д К}\right) \ln C\left[\text { кВт.год } / \mathrm{m}^{3}\right] .
$$

Серед способів зменшення темпів зростання площ земельних ділянок під захоронення ТПВ найбільш дієвими $є$ : ̈̈хн ущільнення на карті полігону за допомогою бульдозерів та збільшення загальної висоти складування, що дозволяє у декілька разів зменшити потребу в земельних ділянках.

Потреба в бульдозерах на виконання технологічних операцій ущільнення ТПВ на карті полігона для зменшення темпів зростання площі полігона, може бути визначена за формулою (Березюк, 2016c)

$$
N_{\sigma}=\frac{2 h\left(37,73-1,923 h+0,06021 n-2,163 \cdot 10^{-3} h n+0,03561 h^{2}+5,849 \cdot 10^{-5} n^{2}\right)}{V_{\sigma} K_{B} b_{\sigma} T d(0,85+0,2134 h)} \text { [од.], }
$$


де $h$ - висота (глибина) складування ТПВ, м;

$n$ - середня чисельність обслуговуваного населення, тис. осіб;

$v_{\sigma}$ - експлуатаційна швидкість бульдозера, м/год (до 3 км/год);

$K_{6}-$ коефіцієнт використання бульдозера (за зміну) за часом $(0,7 \ldots 0,75)$;

$b_{\sigma}$ - ширина смуги, що ущільнюється за 1 проїзд бульдозера, м;

$d$ - товщина шару ТПВ, що формується за один проїз, м;

$T$ - тривалість робочої зміни, год (8 або 11,5 год).

Рівняння регресії, що описує залежність кількості сміттєспалювальних заводів (СС3) в різних країнах від основних факторів впливу виглядає наступним чином (Березюк, 2015b)

$$
\begin{aligned}
& n_{C С 3}=10 \\
& \times \frac{n_{u}}{S_{k p}} U+3,728 \frac{B B \Pi}{n_{\mu}} I P Л \Pi-8,254 \cdot 10^{-4} \frac{B B \Pi}{n_{u}} U-2,416 \cdot 10^{-5}\left(\frac{n_{H}}{S_{k p}}\right)^{2}-0,008273\left(\frac{B B \Pi}{n_{u}}\right)^{2}+0,005603 U^{2}
\end{aligned}
$$

Одним із шляхів поводження з ТПВ $є$ отримання біогазу. Одержання біогазу в анаеробному процесі відбувається в безкисневому середовищі, тому для його реалізації необхідний закритий резервуар у вигляді спеціально сконструйованого стаціонарного біореактора. У залежності від мети застосування методу використовують біореактори, що можуть бути виготовлені або з металу, або з залізобетону і які обладнані пристроями подачі тепла різної конструкції, що забезпечують у біореакторі необхідну температуру для підтримки відповідного анаеробного режиму. Отриманий біогаз можна розділити сепаратором газу на метан і суміжні гази. Очищений метан може використовуватися для виробництва електроенергії або тепла (Европейское Сообщество, 2008), необхідних для енергетичної незалежності України.

Об'єм біореактора для аеробного розкладання ТПВ визначається за формулою (О. Березюк, Лемешев, \& Л. Березюк, 2014)

$$
V_{\text {БP }}=1125 e^{0,004303 m_{\text {TIB., }}}\left[\mathrm{M}^{3}\right],
$$

де $m_{\text {Тпв.д }}$ - добова маса ТПВ, що перероблюються, т/добу.

Ефективність впровадження запропонованого практич ного заняття перевірялась в декількох експериментальних групах $з$ різною успішністю. В цих групах під час вивчення дисципліни БЖД проводилось практичне заняття на тему: «Дослідження забруднення навколишнього середовища твердими побутовими відходами та розрахунок параметрів машин та обладнання для мінімізації негативного впливу на нього», методика інженерних розрахунків якого покладена в основу розв'язання однієї із задач розрахунково-графічної роботи з даної дисципліни. Порівняння результатів тестового контролю 3 перевірки ефективності впровадження запропонованого практичного заняття за методиками, наведеними в роботах (Кобилянський, 2009; Ковальчук, \& Когут, 2008), узагальнено в табл. 2 та здійсне но їхню графічну інтерпретацію, показану на рис. 1.

Таблиця 2 - Порівняння результатів тестового контролю

\begin{tabular}{|l|c|c|c|c|c|c|}
\hline \multirow{2}{*}{\begin{tabular}{|l} 
Показники \\
\cline { 2 - 7 }
\end{tabular}} & $\mathrm{E}-1$ & $\mathrm{~K}-1$ & $\begin{array}{c}\text { Критичне } \\
\text { значення }\end{array}$ & $\mathrm{E}-2$ & $\mathrm{~K}-2$ & $\begin{array}{c}\text { Критичне } \\
\text { значення }\end{array}$ \\
\hline Кількість студентів & 14 & 12 & - & 8 & 12 & - \\
\hline Середній бал $\bar{a}$ & 72,1 & 70,6 & - & 86,9 & 81,1 & - \\
\hline Дисперс ія $\bar{S}^{2}$ & 178,0 & 128,4 & - & 103,9 & 168,6 & - \\
\hline F-критерій Фішера & \multicolumn{2}{|c|}{1,39} & 2,63 & & 1,62 & 3,60 \\
\hline т-критерій Стьюдента & \multicolumn{2}{|c|}{0,32} & 2,06 & \multicolumn{2}{|c|}{1,06} & 2,10 \\
\hline
\end{tabular}


Як видно з порівняння результатів тестового контролю, успішність студентів експериментальних груп за 100-бальною шкалою виявилася значно вищою, ніж успішність студентів контрольних груп.

Отже, на підставі зіставлення й порівняння експериментальних даних, одержаних у результаті дослідження, можна стверджувати про ефективність впровадження запропонованого практичного заняття з безпеки життєдіяль ності у навчальний процес.

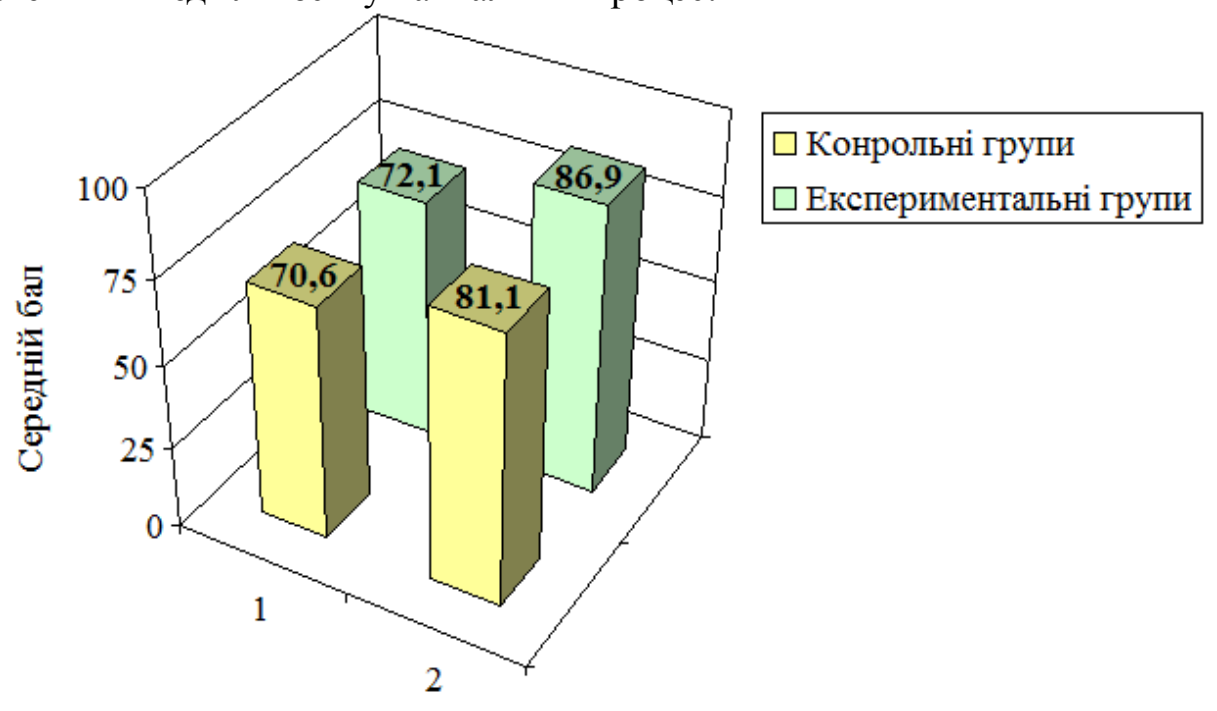

Рисунок 1 - Графічна інтерпретація результатів тестового контролю

\section{Висновки}

1. Запропонована методика інженерних розрахунків, яка може бути використана під час проведення практичного заняття «Дослідження забруднення навколишнього середовища твердими побутовими відходами та розрахунок параметрів машин та обладнання для мінімізації негативного впливу на нього» 3 дисципліни безпека життєдіяльності, що сприятиме поглибленню знань 3 питань охорони навколишнього природного середовища майбутніх фахівців.

2. Встановлено на підставі зіставлення й порівняння експериментальних даних, одержаних у результаті дослідження, що впровадження запропонованого практич ного заняття з безпеки життєдіяльності у навчальний процес $є$ ефективним.

\section{СПИСОК ПОСИЛАНЬ}

Березюк, О. В. (2011). Визначення параметрів впливу на шляхи поведінки з твердими побутовими відходами. Сучасні технології, матеріали і конструкції у будівництві: науково-технічний збірник, 2(10), 64-66.

Березюк, О. В. (2015а). Моделювання питомих енерговитрат очищення грунтів полігонів твердих побутових відходів від забруднення важкими металами. Комунальне господарство міст. Серія: безпека життєдіяльності людини - освіта, наука, практика, 1(120), 240-242.

Березюк, О. В. (2015b). Регресія кількості сміттєспалювальних заводів. Сборник научных трудов SWorld, 1(38), T. 2, 63-66.

Березюк, О. В. (2015c). Удосконалення математичної моделі питомих енерговитрат очищення трунтів полігонів твердих побутових відходів від забруднення важкими металами, Матеріали II Міжнародної науково-практичної конференції «Екологічна безпека як основа сталого розвитку суспільства. Свропейський досвід і перспективи». Львів: ЛДУ БЖД.

Березюк, О. В. (2016а). Моделирование распространенности повторного использования твердых бытовых отходов, Сборник материалов международной научно-практической конференции «Актуальные проблемы архитектуры, строительства, энергоэффектив ности и экологии - 2016». Тюмень, Россия: ФГБОУВО «Тюменский индустриальный универс итет».

Березюк, О. В. (2016b). Определение затрат на очистку зоны загрязнения тяжельми металлами грунтов близлежащих к полигонам твердых бытовых отходов, Материалы XV Международ- 
ной научно-практической конференции «Роль бизнеса и власти в развитии агропромышленного комплекса». Барнаул, Россия: Алтайский дом печати.

Березюк, О. В. (2016c). Усовериенствование математической модели необходимого количества машин для выполнения технологических операций уплотнения на полигоне твердых бытовых отходов, Сборник научных трудов молодых ученых, аспирантов, студентов и преподавателей VII молодежного экологического Конгресса «Северная Пальмира». Санкт-Петербург, Россия: СПб НИЦЭБ РАН.

Березюк, О. В. (2017). Визначення енерговитрат на очищення трунтів навколо полігонів твердих побутових відходів від забруднення важкими металами, Збірник наукових праць всеукраїнської науково-технічної конференції молодих учених та студентів «Еколого-енергетичні проблеми сучасності». Одеса: ОНАХТ.

Березюк, О. В., \& Березюк, Л. Л. (2016). Моделювання поширеності компостування як методу поводження $з$ твердими побутовими відходами. Вісник Вінницького політехнічного інституту, 1, 33-38.

Березюк, О. В., Лемешев, М. С., \& Березюк, Л. Л. (2014). Регрессионная зависимость объёма биореактора от суточной массы перерабатываемых твердых бытовых отходов. Оралдың zыльым жариысы (Уральский научный вестник, Казахстан), 42(121), 58-62.

Европейское Сообщество INTERREG IIIA. (2008). Управление твёрдыми бытовыми отходами. Раздельный сбор и сортировка отходов: Проект «Кооперация в совместном создании системы управления отходами в Псковской области».

Кобилянський, О.В. (2009). Міжпредметні зв'язки та особливості викладання безпеки життєдіяльності бакалаврам економічного спрямування. Вісник Вінницького політехнічного інститу$m y, 6,114-120$.

Кобилянський, О. В. (2012). Практичні аспекти викладання нормативної дисципліни Безпека життєдіяльності у вищих навчальних закладах. Наукові записки Віннищького державного педагогічного університету імені Михайла Кочюбинського. Серія: Педагогіка і психологія, 38, 61-66.

Ковальчук, Л., \& Когут, І. (2008). Міжпредметні зв'язки у процесі вивчення хімії в загальноосвітній школі. Вісник Львівського університету. Серія педагогічна, 23, 80-89.

Лысенко, Л., Пономарев, М., \& Корнилович, Б. (2001). Перспективы решения проблемы загрязнения почв тяжелыми металлами. Экотехнологии и ресурсосбережение, 4, 59-63.

Міністерство освіти і науки, молоді та спорту України. (2011). Типова навчальна програма нормативноїдисципліни «Безпека життєдіяльності» для вищих навчальних закладів. Київ: МОНМСУ.

\section{REFERENCES}

Bereziuk, O. V. (2011). Vyznachennia parametriv vplyvu na shliakhy povedinky z tverdymy pobutovymy vidkhodamy. Suchasni tekhnolohii, materialy i konstruktsii u budivnytstvi: naukovo-tekhnichnyi zbirnyk, 2(10), 64-66.

Bereziuk, O. V. (2015a). Modeliuvannia pytomykh enerhovytrat ochyshchennia gruntiv polihoniv tverdykh pobutovykh vidkhodiv vid zabrudnennia vazhkymy metalamy. Komunalne hospodarstvo mist. Seriia: bezpeka zhyttiediialnosti liudyny - osvita, nauka, praktyka, 1(120), 240-242.

Bereziuk, O. V. (2015b). Rehresiia kilkosti smittiespaliuva lnykh zavodiv. Sbornyk nauchnykh trudov SWorld, 1(38), T. 2, 63-66.

Bereziuk, O. V. (2015c). Udoskonalennia matematychnoi modeli pytomykh enerhovytrat ochyshchennia gruntiv polihoniv tverdykh pobutovykh vidkhodiv vid zabrudnennia vazhkymy metalamy, Materialy II Mizhnarodnoi naukovo-praktychnoi konferentsii "Ekolohichna bezpeka yak osnova staloho rozvytku suspilstva. Yevropeiskyi dosvid i perspektyvy". Lviv: LDU BZhD.

Bereziuk, O. V. (2016a). Modelyrovanye rasprostranennosty povtornoho yspolzovanyia tverdykh bytovykh otkhodov, Sbornyk materyalov mezhdunarodnoi nauchno-praktycheskoi konferentsyy "Aktualnye problemy arkhytektury, stroytelstva, enerhoeffektyvnosty y ekolohyy - 2016". Tiumen, Rossyia: FHBOUVO "Tiumenskyi yndustrya lnyi unyversytet".

Bereziuk, O. V. (2016b). Opredelenye zatrat na ochystku zony zahriaznenyia tiazhelymy metallamy hruntov blyzlezhashchykh $k$ polyhonam tverdykh butovykh otkhodov, Materyaly XV Mezhdunarodnoi nauchno-praktycheskoi konferentsyy "Rol byznesa y vlasty v razvytyy ahropromyshlennoho kompleksa". Barnaul, Rossyia: Alta iskyi dom pechaty. 
Bereziuk, O. V. (2016c). Usovershenstvovanye matematycheskoi modely neobkhodymoho kolychestva mashyn dlia vypolnenyia tekhnolohycheskykh operatsyi uplotnenyia na polyhone tverdykh butovykh otkhodov, Sbornyk nauchnykh trudov molodykh uchenykh, aspyrantov, studentov y prepodavatelei VII molodezhnoho ekolohycheskoho Konhressa "Severnaia Palmyra". Sankt-Peterburh, Rossyia: CPb NYTsEB RAN.

Bereziuk, O. V. (2017). Vyznachennia enerhovytrat na ochyshchennia gruntiv navkolo polihoniv tverdykh pobutovykh vidkhodiv vid zabrudnennia vazhkymy metalamy, Zbirnyk naukovykh prats vseukrainskoi naukovo-tekhnichnoi konferentsii molodykh uchenykh ta studentiv "Ekoloho-enerhetychni problemy suchasnosti”. Odesa: ONAKhT.

Bereziuk, O. V., \& Bereziuk, L. L. (2016). Modeliuvannia poshyrenosti kompostuvannia yak metodu povodzhennia z tverdymy pobutovymy vidkhodamy. Visnyk Vinnytskoho politekhnichnoho instytutu, 1, 33-38.

Bereziuk, O. V., Lemeshev, M. S., \& Bereziuk, L. L. (2014). Rehressyonnaia zavysymost ob'yema byoreaktora ot sutochnoi massy pererabatyvaemykh tverdykh butovykh otkhodov. Oraldyn gylym zharshysy (Uralskyi nauchnyi vestnyk, Kazakhstan), 42(121), 58-62.

Evropeiskoe Soobshchestvo INTERREG IIIA. (2008). Upravlenye tvyordymy bytovymy otkhodamy. Razdelnyi sbor y sortyrovka otkhodov: Proekt "Kooperatsyia $v$ sovmestnom sozdanyy systemy upravlenyia otkhodamy v Pskovskoi oblasty".

Kobylianskyi, O. V. (2009). Mizhpredmetni zviazky ta osoblyvosti vykladannia bezpeky zhyttiediialnosti bakalavram ekonomichnoho spriamuvannia. Visnyk Vinnytskoho politekhnichnoho instytutu, 6, 114-120.

Kobylianskyi, O. V. (2012). Praktychni aspekty vykladannia normatyvnoi dystsypliny Bezpeka zhyttiediialnosti u vyshchykh navchalnykh zakladakh. Naukovi zapysky Vinnytskoho derzhavnoho pedahohichnoho universytetu imeni Mykhaila Kotsiubynskoho. Seriia: Pedahohika i psykholohiia, 38, 61-66.

Kovalchuk, L., \& Kohut, I. (2008). Mizhpredmetni zviazky u protsesi vyvchennia khimii v zahalnoosvitnii shkoli. Visnyk Lvivskoho universytetu. Ceriia pedahohichna, 23, 80-89.

Lysenko, L., Ponomarev, M., \& Kornylovych, B. (2001). Perspektyvy reshenyia problemy zahriaznenyia pochv tiazhelymy metallamy. Ekotekhnolohyy y resursosberezhenye, 4, 59-63.

Ministerstvo osvity i nauky, molodi ta sportu Ukra iny. (2011). Typova navchalna prohrama normatyvnoi dystsypliny "Bezpeka zhyttiediialnosti" dlia vyshchykh navchalnykh zakladiv. Kyiv: MONMSU.

\section{Олег Березюк}

\section{Впровадження практичного заняття «Дослідження забруднення нав колишнього середовища твердими побутовими відходами та розрахунок параметрів машин та обладнання для мінімізації негативного впливу на нього» 3 дисципліни безпека життсдіяльності}

В роботі запропонована методика інженерних розрахунків, яка необхідна для впровадження практичного заняття «Дослідження забруднення навколишнього середовища твердими побутовими відходами та розрахунок параметрів машин та обладнання для мінімізації негативного впливу на нього» 3 дис ципліни безпека життєдіяльності для сприяння поглибленню знань 3 питань охорони навколишнього природного середовища майбутніх фахівців. Запропонована методика інженерних розрахунків включає в себе визначення: пошире ності основних методів поводження з твердими побутовими відходами, кратності перевищення граничнодопустимої концентрації важких металів у грунтах на різних відстанях від полігонів захоронення, питомих енерговитрат очищення грунтів полігонів методом електрохімічної ремедіації від забруднення важким и металами, потреби в бульдозерах на виконання технологічних операцій ущільнення твердих побутових відходів на карті полігона для зменшення темпів зростання його площі, кількості сміттєспалювальних заводів, об'єму біореактора для аеробного розкладання твердих побутових відход ів. Серед факторів впливу на поширеність основних методів поводження з твердими побутовими відходами та кількість сміттєспалювальних заводів розглядались такі: густота населення, ВВП на душу населення, співвідношення витрат на спалювання та захоронення твердих побутових відходів, індекс розвитку 
людського потенціалу, середня географічна широта, частка сільського населення, значення показника статусу держави за фактором «природні ресурси». Питомі енерговитрати очищення грунт ів полігонів захоронення твердих побутових відход ів методом електрохімічної ремедіації від забруднення визначалися в залежності від фактичної та граничнодопустимої концентрацій важких металів. Потреба в бульдозерах на виконання технологічних операцій ущільнення твердих побутових відходів на карті полігона визначалася в залежності від їхньої висоти складування, середньої чисельності обслуговуваного населення, експлуатаційних характеристик бульдозера. Під час розрахунку об `єму біореактора для аеробного розкладання твердих побутових відходів враховувалась їхня добова маса, що переробляється. На підставі зіставлення й порівняння експериментальних даних, одержаних у результаті дослідження, встановлено, що впровадження запропонованого практичного заняття з безпеки життєдіяльності у навчальний процес є ефективним.

Ключові слова: безпека життєдіяльності; практичне заняття; охорона навколишнього природного середовища; забруднення; тверді побутові відходи; розрахунок параметрів машин та обладнання.

Олег Березюк - кандидат технічних наук, доцент, доцент кафедри безпеки життєдіяльності та педагогіки безпеки, Вінницький національний технічний університет, Вінниця, e-mail: berezyukoleg@i.ua

\section{O. Bereziuk}

\section{Implementation practical lesson "Study of environmental pollution by solid domestic wastes and parameters calculation of machines and equipment for minimization of negative influence on it" on discipline life safety}

In article the methodic of engineering calculations is proposed that is necessary for implementation of the practical lesson "Study of environmental pollution by solid domestic wastes and parameters calculation of machines and equipment for minimization of negative influence on it" on the discipline of life safety for the promotion of know ledge development on environmental issues of future specialists. The proposed methodology for engineering calculations includes the definition: the prevalence of the basic methods of handling solid domestic wastes, the multiplicity of exceeding the permissible concentration of heavy metals in soils at different distances from landfills, specific energy consumption, cleaning of soils of landfills by electrochemical remediation from heavy metal contamination, bulldozer requirements on performance of technological operations of compaction of solid domestic wastes on the map of the landfill to reduce the rate of growth I had space, the number of combustion plants, the volume of the bioreactor for aerobic decomposition of solid domestic wastes. Among the factors influencing the prevalence of the basic methods of handling solid domestic wastes and the number of incinerators, the following were considered: population density, GDP per capita, the ratio of expenditures on incineration and dis posal of solid domestic wastes, the index of human development, the average geographical latitude, the share of rural population, the value of the indicator of state status on the factor of "natural resources". The specific energy costs of soil clearing of solid waste disposal sites by the method of electrochemical remediation from pollution were determined depending on the actual and maximum permissible concentrations of heavy metals. The need for bulldozers to perform technological operations of compaction of solid domestic wastes on the map of the landfill was determined depending on their storage height, the average number of serviced population, performance characteristics of the bulldozer. During the calculation of the volume of bioreactor for the aerobic decomposition of solid domestic wastes, their daily weight was taken into account. On the basis of comparison of experimental data obtained in the course of the research, it was established that the implementation of the proposed practical training on life safety in the educational process is effective.

Keywords: life safety, practice lesson, protection of the environment, pollution, solid domestic wastes, parameters calculation of machines and equipment.

Bereziuk Oleg - Cand. Sc. (Eng.), Assistant Professor, Assistant Professor of the Chair of Security of Life and Safety Pedagogic, Vinnytsia National Technical University, Vinnytsia, e-mail: berezyukoleg@i.ua 


\section{Олег Березюк}

\section{Внедрение практического занятия «Исследование загрязнения окружающей среды твердыми бытовыми отходами и расчет параметров машин и оборудования для минимизации негативного влияния на неё» по дисциплине безопасность жизнедеятельности}

В работе предложена методика инженерных расчетов, которая необходима для внедрения практического занятия «Исследование загрязнения окружающей среды твердыми бытовыми отходами и расчет параметров машин и оборудования для минимизации негативного влияния на него» по дисциплине безопасность жизнедеятельности для содействия углублению знаний по вопросам охраны окружающей природной среды будущих специалистов. Предложенная методика инженерных расчетов включает в себя определение: распространенности основных методов обращения с твердыми бытовыми отходами, кратности превышения предельно-допустимой концентрации тяжёлых металлов в грунтах на различных расстояниях от полигонов захоронения, удельных энергозатрат очистки грунтов полигонов методом электрохимической ремедиации от загрязнения тяжёлыми металлами, потребности в бульдозерах на выполнение технологических операций уплотнения твердых бытовых отходов на карте полигона для уменьшения темпов роста его площади, количества мусоросжигательных заводов, объема биореактора для аэробного разложения твердых бытовых отходов. Среди факторов влияния на распространенность основных методов обращения с твердыми бытовыми отходами и количество мусоросжигательных заводов рассматривались такие: густота населения, ВВП на душу населения, соотношение затрат на сжигание и захоронение твердых бытовых отходов, индекс развития человеческого потенциала, средняя географическая широта, доля сельского населения, значение показателя статуса государства за фактором «природные ресурсы». Удельные энергозатраты очищения грунтов полигонов захоронения твердых бытовых отходов методом электрохимической ремедиации от загрязнения определялись в зависимости от факт ической и предельно-допустимой концентраций тяжёлых металлов. Потребность в бульдозерах на выполнение технологических операций уплотнения твердых бытовых отходов на карте полигона определялась в зависимости от их высоты складирования, средней численности обслуживаемого населения, эксплуатационных характеристик бульдозера. При расчете объема биореактора для аэробного разложения твердых бытовых отходов учитывалась их суточная перерабатываемая масса. На основании сопоставления и сравнения экспериментальных данных, полученных в результате исследования, установлено, что внедрение предложенного практического занятия по безопасности жизнедеятельности в учебный процесс является эффективным.

Ключевые слова: безопасность жизнедеятельности, практическое занятие, охра на окружающей среды, загрязнение, твердые бытовые отходы, расчет параметров машин и оборудования. 